\title{
Food utilisation and digestive ability of aquatic and semi-terrestrial crayfishes, Cherax destructor and Engaeus sericatus (Astacidae, Parastacidae)
}

\author{
Stuart Maxwell Linton • Benjamin J. Allardyce • \\ Wilhelm Hagen · Petra Wencke · Reinhard Saborowski
}

Received: 12 August 2008 / Revised: 15 December 2008 / Accepted: 16 December 2008

(C) Springer-Verlag 2009

\begin{abstract}
Both Engaeus sericatus and Cherax destructor are omnivorous crayfishes consuming a variety of food items. Materials identified in the faeces of both E. sericatus and $C$. destructor consisted of mainly plant material with minor amounts of arthropod animals, algae and fungi. The morphology of the gastric mill of $C$. destructor suggests that it is mainly involved in crushing of food material while the gastric mill of E. sericatus appears to be better suited to cutting of food material. Given this, the gastric mill of E. sericatus may be better able to cut the cellulose and hemicellulose fibres associated with fibrous plant material. In contrast, the gastric mill of $C$. destructor appears to be more efficient in grinding soft materials such as animal protein and algae. Both species accumulated high amounts of lipids in their midgut glands (about $60 \%$ of the dry mass) which were dominated by triacylglycerols $(81-82 \%$ of total lipids). The dominating fatty acids were 16:0, 16:1(n-7), 18:1(n-9), 18:2(n-6), and 18:3(n-3). The two latter fatty
\end{abstract}

Communicated by I. D. Hume.

S. M. Linton $(\bowtie) \cdot$ B. J. Allardyce

School of Life and Environmental Sciences,

Deakin University, Pigdons Road, Geelong,

VIC 3217, Australia

e-mail: slinton@deakin.edu.au

W. Hagen $\cdot$ P. Wencke

Marine Zoology, University of Bremen,

P.O. Box 330 440, 28334 Bremen, Germany

R. Saborowski

Alfred Wegener Institute for Polar and Marine Research, Biologische Anstalt Helgoland, P.O. Box 180,

27483 Helgoland, Germany acids can only be synthesised by plants, and are thus indicative of the consumption of terrestrial plants by the crayfishes. The similarity analysis of the fatty acid patterns showed three distinct clusters of plants and each of the crayfish species. The complement of digestive enzymes, proteinases, total cellulase, endo- $\beta$-1,4-glucanase, $\beta$-glucosidase, laminarinase and xylanase within midgut gland suggests that both $C$. destructor and E. sericatus are capable of hydrolysing a variety of substrates associated with an omnivorous diet. Higher activities of total cellulase, endo$\beta$-1,4-glucanase and $\beta$-glucosidase indicate that $E$. sericatus is better able to hydrolyse cellulose within plant material than $C$. destructor. In contrast to E. sericatus, higher total protease and $N$-acetyl- $\beta$-D-glucosaminidase activity in the midgut gland of $C$. destructor suggests that this species is better able to digest animal materials in the form of arthropods. Differences in total cellulase and gastric mill morphology suggest that $E$. sericatus is more efficient at digesting plant material than $C$. destructor. However, the contents of faecal pellets and the fatty acid compositions seem to indicate that both species opportunistically feed on the most abundant and easily accessible food items.

Keywords Engaeus sericatus . Cherax destructor . Crayfish · Feeding $\cdot$ Nutrition $\cdot$ Stomach content $\cdot$ Gastric mill $\cdot$ Midgut gland $\cdot$ Storage lipids $\cdot$ Fatty acids . Digestive enzymes

\section{Introduction}

Crustaceans have successfully adapted to aquatic environments. In the oceans, they represent the most abundant and the most diverse phylum inhabiting pelagic as well as benthic systems. They often appear in high numbers from 
the surface layers, down to deep-sea canyons, and thermal vents. Most of the members of crustacean taxa have adapted to life in freshwater systems as well. However, only a number of species from a few taxonomic groups (e.g. isopods, anomurans and brachyurans) have successfully invaded land.

The colonisation of land requires the adoption of a terrestrial diet. For omnivorous/detritivorous species, this involves consuming terrestrial plant material such as grasses, leaf litter, fruits and seeds. There are a number of disadvantages associated with the consumption of plant material. Notably, it is tough and fibrous due to the presence of large amounts of cellulose and hemicellulose associated with its cell walls. This makes plant material slow and difficult to digest (Linton and Greenaway 2007). Also given the low amounts of protein, plant material is of poor nutritive quality. To be able to utilise plant material as a nutrient source, decapod crustaceans require a gastric mill, this initially reduces the cellulose and hemicellulose fibres into small particles. These particles are then enzymatically attacked by specialised enzymes such as cellulases and hemicellulases, which hydrolyse them to their component sugars (Linton and Greenaway 2007).

Elucidating whether terrestrial digestive adaptations occur requires examination of a group of closely related crustaceans that contain both aquatic and terrestrial species. The Australian parastacid crayfishes represent such a group (Crandall et al. 1999); members may be omnivorous aquatic species such as Cherax destructor or semi terrestrial burrowing species such as Engaeus sericatus. C. destructor is an aquatic freshwater crayfish, commonly known as a yabby, and is found living in rivers, ponds, dams, and billabongs throughout eastern and central Australia (Merrick 1993; Jones and Morgan 1994). Yabbies are considered omnivorous, feeding on a range of plant, algae, animal and detrital material (Goddard 1988; Faragher 1983; Beatty 2006). Burrowing parastacid crayfish, such those of the genus Engaeus are endemic to southeastern Australia and Tasmania. Engaeus are a semiterrestrial genus, they require access to a permanent source of water but also engage in significant terrestrial activity during rain or at night to forage or mate (Horwitz 1990; Growns and Richardson 1988; Suter and Richardson 1977). They inhabit swampy areas and build burrows with characteristic chimneys (Horwitz 1990; Growns and Richardson 1988). Their burrows may consist of either a single burrow or a complex of many burrows with interconnecting tunnels. At least one of these burrows extends down to the water table or contains water. Some of the burrows terminate as feeding chambers under the roots of plants. As a group, Engaeus species are omnivorous feeding on plants roots, other plant material, and arthropods (Growns and Richardson 1988; Suter and Richardson 1977).
The functional morphology of the gastric mill, the composition of storage lipids, as well as the activities of the predominantly expressed digestive enzymes correlate well with dietary preferences (e.g. Heinzel 1988; Salindeho and Johnston 2003; Dalsgaard et al. 2003; Linton and Greenaway 2004). The crustacean gastric mill is a part of the cardiac stomach. It consists of two lateral teeth and one medial tooth. In general, macrophagus crabs that consume large food items such as animals, macro-algae and plants have robust, dentate, heavily calcified gastric mills. In contrast, microphagus/detritivorous crabs, which consume soft food material such as decayed seagrass, epiphytic algae and bacteria, have less calcified gastric mills which may possess stiff setae instead of being dentate (Kunze and Anderson 1979; Heeren and Mitchell 1997; Salindeho and Johnston 2003; Martin et al. 1998). Within the macrophagus crabs, the morphology of the medial and lateral teeth correlates well with diet. The teeth of the gastric mill from the herbivorous sesarmid crab, Neosarmatium smithii possesses low heavy transverse dentate ridges that interlock for cutting tough fibrous plant material (Giddins et al. 1986). The lateral teeth of omnivorous crabs such as Nectocarcinus tuberculosus possess cusps for cutting food material and vertical ridges, which interact with surfaces on the medial tooth for grinding (Salindeho and Johnston 2003). Thus, the gastric mills of such omnivorous species appear to be adapted for mastication of both soft and hard food material. Lateral teeth from the gastric mill of carnivorous crabs such as Ozius truncatus have large flattened molar processes, which grind against robust ridges on the medial tooth for pulverising the relatively soft animal material (Skilleter and Anderson 1986). Although it has not been examined, the gastric mill of terrestrial omnivorous species is likely to possess morphological adaptations, such as heavily dentate teeth with low transverse ridges, for grinding and cutting of this tough fibrous material.

Lipids are major energy storage products in crustaceans. They accumulate in the midgut glands and potentially reflect the fatty acid composition of the preferred food items, given the ingested fatty acids may be incorporated in storage triacylglycerols without biochemical modification by the organism (Nelson and Cox 2005). Furthermore, the presence of fatty acids, such as poly unsaturated ones, which are known to be synthesised by plants and not animals, may provide valuable information about the importance of dietary plant material during the period in which the storage of lipids took place (Nelson and Cox 2005). Some fatty acids may even serve as specific trophic markers as shown in marine environments (reviewed by Dalsgaard et al. 2003).

The biochemical degradation of food items is facilitated by a set of highly active digestive enzymes, which are synthesized in the midgut gland but subsequently, accumulate 
in the stomach. Carnivorous species may produce high levels of proteases such as trypsin and chymotrypsin for digesting protein; omnivorous species express proteases and carbohydrases such as $\alpha$-amylase and $\alpha$-glucosidase; algal and phytoplankton feeders have high levels of laminarinases for digesting laminarin, the major storage polysaccharide of algae; and herbivorous species show high activities of cellulase and hemicellulase enzymes for hydrolysing cellulose and hemicellulose found in plant cell walls (Johnston and Yellowlees 1998; Linton and Greenaway 2004; Johnston and Freeman 2005; Crawford et al. 2005). Whilst the complement of digestive enzymes produced by terrestrial omnivorous species is largely unknown, it is most likely to be dominated by high activities of cellulase and hemicellulase enzymes. These enzymes may be required to digest the terrestrial plant material. Indeed, in terrestrial species, the cellulase activity may be higher while the laminarinase activity may be lower than that of closely related aquatic species, given the former may consume more plant material and fewer algae.

Little is known about the biochemical and morphological adaptations that Engaeus may possess towards an omnivorous diet. Given that they essentially forage in a terrestrial environment, they may possess adaptations such as those hypothesised above which enable them to efficiently digest terrestrial plant material. To elucidate dietary preference and biochemical and morphological adaptations that Engaeus may possess, we examined the enzyme and lipid complement and morphology of the gastric mill of E. sericatus. E. sericatus is endemic to ephemeral creeks south and southwest of the Otway ranges in central Victoria, Australia (Horwitz 1990). Possible adaptations to a terrestrial plant diet were elucidated by comparing the enzyme complement, activity and morphology of the gastric mill to that of a close aquatic relative, $C$. destructor. The importance of terrestrial plant material in the diet was assessed by examining the presence of signature lipids, produced by plants, in the midgut glands of both species.

\section{Materials and methods}

\section{Origin of samples}

Crayfishes, $C$. destructor and E. sericatus, were caught in November 2006 in Victoria, Australia. C. destructor were captured from the ponds of Deakin University (Waurn Ponds Campus, Geelong) with Jarvis Walker yabby traps. E. sericatus were collected from Birragurra creek at Birragurra. They were dug out of muddy soil, roughly cleaned and immediately transferred to the laboratories of Deakin University while being kept chilled. In the laboratory, they were placed into separate tubes or beakers. The animals were left in these facilities overnight to defecate. The next day, the animals were removed and the faeces were collected using forceps and preserved in $70 \%$ alcohol. Pieces of the most abundant plants from the sampling sites, including roots, stalks, and leaves were taken to the laboratory and were deep-frozen for later fatty acid analysis.

Dissection of the digestive organs

Prior to dissection, the animals were anaesthetized by cooling them for $30 \mathrm{~min}$ on ice. The lengths of the animals were measured from the tip of the rostrum to the end of the telson and the fresh weights were determined. The carapace was then opened by lateral incisions with scissors and was carefully detached dorsally from the inner organs. The midgut gland tissue was completely removed and weighed. The mass of the midgut gland was calculated in relation to the total body mass of the animal providing the midgut gland index (MGI). An aliquot of tissue was immediately used to prepare extracts for cellulase, hemicellulase and chitinase assays while another aliquot was deep-frozen in liquid nitrogen for later proteinase assays and lipid determinations. The stomach was completely removed and stored in $70 \%$ ethanol for later scanning electron microscopy.

Anatomy of gastric mill

Cardiac stomachs of $C$. destructor and E. sericatus containing the gastric mills were carefully dissected out of the animal. Connective tissue surrounding the stomachs was removed to reveal the gastric mill by careful dissection and by soaking the stomachs in $5 \%$ sodium hydroxide for 2-3 h. Gastric mills were then rinsed with distilled water, dried in graded ethanol $(80,90$ and $100 \%)$ and air dried overnight at room temperature. Dried samples were then mounted on an scanning electron microscope stub using double sided carbon tape (Spi carbon tape, 5072) and sputter coated with gold using a sputter coater. Gold-coated samples of the gastric mills were examined using a Phillips XL20 scanning electron microscope.

Analysis of food items in the faeces

Food items within the faeces were identified using light microscopy. The faecal samples were smeared onto a glass slide, stained with $0.5 \%(\mathrm{w} / \mathrm{v})$ Congo red and examined under a compound light microscope. Plant items were identified by the presence of cellulose fibres, water vascular bundles, or cells with thick cell walls. Animal material was identified by the fragments of chitinous arthropod appendages. Algal filaments were identified by chains of empty cells with thick cell walls. Hyphae containing sporocysts were deemed as fungi. 
Lipid and fatty acid analysis

Subsamples of midgut gland tissue for later lipid and fatty acid analysis were transferred at $-198^{\circ} \mathrm{C}$ to Germany. The samples were lyophilised for $48 \mathrm{~h}$ and weighed. Total lipids were extracted with dichloromethane/methanol $(2: 1 \mathrm{v} / \mathrm{v})$ and determined gravimetrically (Hagen 2000). Lipid classes were separated and analysed by thin-layer chromatography flame ionisation detection (TLC-FID) with an IATROSCAN analyser (Iatron Laboratories, Inc., MK-5 TLC/FID Analyser) as per Fraser et al. (1985). The extracted lipids were hydrolysed and the fatty acids were converted to methyl ester derivatives (FAMEs). The conversion was carried out for $4 \mathrm{~h}$ at $80^{\circ} \mathrm{C}$ in a solution of methanol and 3\% (v/v) sulphuric acid (Kattner and Fricke 1986). After cooling to room temperature, $4 \mathrm{ml}$ of deionised water was added. FAMEs were extracted with hexane $(3 \times 1.7 \mathrm{ml})$ and analysed in a gas chromatograph (Hewlett Packard Model No 6890A). The device was equipped with a DB-FFAP column (30 $\mathrm{m}$ length, $0.25 \mathrm{~mm}$ inner diameter, $0.25 \mu \mathrm{m}$ film thickness). The separation was performed by using temperature programming and helium as carrier gas. FAMEs were detected by flame ionisation and identified by comparing retention time data with those obtained from standard mixtures.

\section{Enzyme assays}

Extracts for enzyme assays were homogenised in $0.1 \mathrm{~mol}^{-1}$ sodium-acetate buffer ( $\mathrm{pH}$ 5.5) containing $2 \mathrm{mmol}^{-1}$ dithioerythritol as a reducing reagent or in demineralised water. Depending on their mass, the midgut gland samples (50-1,000 mg) were homogenised in 1-3 ml of liquid using a Polytron homogenizer or an ultrasonic cell disruptor (Branson, Sonifier). The homogenates were centrifuged for $10 \mathrm{~min}$ at $10,000 \mathrm{~g}$ and at $4^{\circ} \mathrm{C}$. The supernatants (extracts) were aliquoted and stored frozen until enzyme analysis.

Assays for cellulase [total cellulase, endo- $\beta$-1,4-glucanase (EC 3.2.1.4) and $\beta$-glucosidase (EC 3.2.1.21)] and hemicellulase (laminarinase [endo- $\beta$-1,3-glucanase (EC 3.2.1.39)], licheninase [endo- $\beta-1,3 ; 1,4$ glucanase (EC 3.2.1.73)], xylanase [endo- $\beta-1,4$-xylanase (EC 3.2.1.8)]) were carried out as described by Linton and Greenaway (2004). Total cellulase activity was measured in $50 \mu \mathrm{l}$ aliquots of enzyme extract. Aliquots of $25 \mu$ of the enzyme extract were used to measure the activities of $\beta$-glucosidase, laminarinase, xylanase and lichenase. Ten microlitre aliquots of the enzyme extract were used in the endo- $\beta-1,4-$ glucanase assays. All enzyme assays were incubated at $30^{\circ} \mathrm{C}$. Total cellulase and $\beta-1,4$-glucosidase (E.C. 3.2.1.21) activities were measured as the rate of glucose production from microcrystalline cellulose (Sigmacell 20, Sigma S-3504) and cellobiose (Sigma, C-7252), respectively. Endo- $\beta-1$, 4-glucanase (E.C. 3.2.1.4), laminarinase (EC 3.2.1.39), lichenase (EC 3.2.1. 73) and xylanase (EC 3.2.1.8) activities were measured as the rate of reducing sugar production from the hydrolysis of the respective substrates, carboxymethyl cellulose (Sigma, C-5678), laminarin (from Laminaria digitata; Sigma, L-9634), lichenan (from Cetraria islandica; Sigma L-6133) and xylan (from birchwood, Betula; Sigma X-0502).

Chitinase $\quad[1,4-\beta$-poly- $N$-acetylglucosaminidase $\quad(\mathrm{EC}$ 3.2.1.14)] and NAGase [ $N$-acetyl- $\beta$-D-glucosaminaidase (EC 3.2.1.52)] were assayed as per Saborowski et al. (1993). Chitinase activity was measured as the release of Remazol Brillant blue from the substrate, CM-Chitin-RBB (Loewe Biochemica, 04106). NAGase activity was determined by the release of $p$-nitrophenol from $p$-nitrophenyl$N$-acetyl- $\beta$-D-glucosaminide [NAGpnp, (Sigma N-9376)].

The assays for total proteinase, trypsin-like and chymotrypsin-like activities were as outlined by Saborowski et al. (2004). Total proteolytic activity was determined by the release of azo dye from the hydrolysis of azocasein (Fluka, 11615). Trypsin-like, chymotrypsin-like and alanine-aminopetidase enzyme activities (E.C. 3.2.1) were determined by the release of $p$-nitroaniline from the substrates $N_{\alpha}$-Benzoyl-L-arginine-4-nitroanilide-hydrochloride (L-BAPNA, Fluka 12915) (Erlanger et al. 1961), $N$-Succinyl-Ala-AlaPro-Phe-p-nitroanilide (SAAPPNA, Sigma S7388) and L-Alanine- $p$-nitroanilide-hydrochloride (Sigma, A 9325).

Inhibition assays of proteinases were carried out after Teschke and Saborowski (2005) with the cysteine proteinases inhibitor Trans-Epoxy-Succinyl-L-Leucylamido-(4Guanidino)-Butane (E64, Sigma E 3132) and the serine proteinase inhibitor 4-(2-Aminoethyl)enzenesulfonyl-fluorid Hydrochloride (AEBSF, Merck 124839). The inhibited samples were subjected to proteinase assays with azocasein as substrate.

Protein concentrations in the enzyme extracts were determined after Bradford (1976) using a commercial dye reagent (BioRad 500-0006). Bovine $\gamma$-globuline (MP Biochemicals 11BSAG010) at concentrations of $0-1 \mathrm{mg} \mathrm{ml}^{-1}$ served as standards.

\section{Statistics}

Statistical analyses were carried out with the computer programs STATISTICA Ver 5.5 (Stats soft) or SigmaStat Ver 3.1 (Systat Software). Tests for normal distribution and equal variances were run initially. Pairwise comparison of data sets was performed using either Student's $t$ test or a Mann-Whitney rank sum test. Means were deemed to be significantly different if the calculated probability of the statistical test was less than 0.05 . 


\section{Results}

Morphometric data

The Cherax-specimens were generally larger than the Engaeus-specimens and had a wider mass range (Table 1). The sex distribution was similar in both species $(25-50 \%$ females). The masses of the midgut glands increased allometrically with the body masses [E. sericatus: Midgut gland mass $(\mathrm{g})=0.0562 \times$ Animal mass $(\mathrm{g})+0.0249$ $\left(r^{2}=0.9659\right), C$. destructor: Midgut gland mass $(\mathrm{g})=$ $0.028 \times$ Animal mass $\left.(\mathrm{g})+0.5742\left(r^{2}=0.8129\right)\right]$. Two individuals of $C$. destructor showed exceptionally small midgut glands: one of them was a gravid female with a depleted midgut gland while the reason for the second deviating animal, a male, remained unclear. The midgut gland indices (MDI) of E. seratus did not vary significantly from those of small $C$. destructor. However, a significant difference appeared between $E$. seratus and large C. destructor as well as between small and large $C$. destructor (Table 1).

Items identified in the faeces

Material identified in the faeces suggested that $E$. sericatus was omnivorous, consuming mainly plant material with minor amounts invertebrates, algae, fungi and invertebrates (Table 2). Of the materials identified, the majority consisted of plant material (leaf fragments with stomata, cellulose bundles constituting the water vascular system and clusters of cells with thick cell walls), with minor amounts of fungi (hyphae with sporocysts) and animal material (fragments of chitinous invertebrate appendages) (Table 2). Substantial amounts of the matter in the feaces could not be identified.

Like E. sericatus, $C$. destructor was an omnivore consuming mainly plant material with significant amounts of filamentous algae and minor amounts of arthropods and fungi (Table 2). The majority of the food material identified in the faeces consisted of plant material in the form of

Table 1 Morphometric data of specimens used in this study

\begin{tabular}{llll}
\hline & $\begin{array}{l}\text { Engaeus } \\
\text { sericatus }\end{array}$ & Cherax destructor \\
\hline Number of animals & 8 & 6 (small) & 5 (large) \\
Length (mm) & $38-60$ & $62-88$ & $111-125$ \\
Sex distribution & $3 \mathrm{f}, 5 \mathrm{~m}$ & $1 \mathrm{f}, 4 \mathrm{~m}$ & $2 \mathrm{f}, 4 \mathrm{~m}$ \\
Fresh mass animal $(\mathrm{g})$ & $1.87-10.92$ & $5.76-16.7$ & $28.6-71.4$ \\
Mass of midgut gland $(\mathrm{g})$ & $0.11-0.61$ & $0.32-1.08$ & $1.65-2.66$ \\
Midgut gland index $(\%)$ & $6.26 \pm 0.23^{\mathrm{a}}$ & $5.89 \pm 0.42^{\mathrm{a}}$ & $3.96 \pm 0.55^{\mathrm{b}}$ \\
\hline
\end{tabular}

Values are given as range between minimum and maximum or as mean values \pm SEM. For the midgut gland index, similar superscript letters indicate similar mean values ( 1 -way ANOVA, $P \geq 0.05$ )
Table 2 Percentages of identifiable items in the faeces [Mean \pm SEM $(n)]$

\begin{tabular}{lcc}
\hline & Cherax destructor & Engaeus sericatus \\
\hline Arthropod fragments & $3.3 \pm 0.8(6)^{\mathrm{a}}$ & $7.4 \pm 3.4(5)^{\mathrm{a}}$ \\
Plant material & $71.7 \pm 13.9(6)^{\mathrm{a}}$ & $89.6 \pm 3.1(5)^{\mathrm{a}}$ \\
Algal filaments & $24.3 \pm 13.1(6)^{\mathrm{a}}$ & $1.2 \pm 1.2(5)^{\mathrm{b}}$ \\
Fungal hyphae & $0.7 \pm 0.7(6)^{\mathrm{a}}$ & $1.8 \pm 1.8(5)^{\mathrm{a}}$ \\
\hline
\end{tabular}

Within a row, similar superscript letters indicate similar means $(P \geq 0.05, t$ test $)$

macerated leaf material and bundles of cellulose fibres comprising the water vascular system. Minor amounts of animal and fungal material were also identified in the faeces. The faeces of both $C$. destructor and E. sericatus contained similar percentages of plant, arthropod and fungal material. Algal filaments in the form of long chains of empty cells, most likely Spirogyra, made up approximately $25 \%$ of the identifiable items in the faeces of C. destructor. This percentage was significantly higher than that in than E. sericatus (Table 2).

Anatomy of gastric mills

\section{Engaeus sericatus}

The medial tooth was part of the urocardiac ossicle (Fig. 1a). The posterior part of the medial tooth protruded ventrally, it curved round and ended in two sharp ventrolateral cusps, which pointed anteriorly. On the lateral sides of the protrusion were deep indentations. Anterior to the protrusion were two lateral ridges, the ends of which terminated as sharp anterior pointing cusps. The urocardiac ossicle immediately anterior to the dentate region of the medial tooth sloped away dorsally.

The lateral tooth was dentate (Fig. 1b). The ventral surface of the lateral tooth possessed eight large curved cusps, which pointed posteriorly. Anterior cusps were larger than the posterior ones, with the size progressively decreasing from anterior to posterior. The largest of the cusps were approximately $250 \mu \mathrm{m}$ long and $200 \mu \mathrm{m}$ wide and decreased in size to approximately $58 \mu \mathrm{m}$. These cusps gave the ventral surface of the lateral tooth a serrated appearance. The cusps from anterior to posterior were progressively rotated so that the last posterior cusp was $90^{\circ}$ to the first anterior cusp (Fig. 1b, c). Next to the first cusp, was a singular ventral cusp (Fig. 1b). Cusp number two was singular. Next to and in line with the remaining six cusps were smaller cusps (Fig. 1b). Dorsal to ventral cusps three and four were smaller singular cusps. On the dorsal side of ventral cusps, numbered five to eight were bumpy ridges. The dorsal surface of the lateral tooth displayed evidence of wear in the form of scoring and indentations. The cusps on 
Fig. 1 Scanning electron micrographs of the gastric mills from Engaeus sericatus $(\mathbf{a}-\mathbf{d})$ and Cherax destructor $(\mathbf{e}-\mathbf{g})$. a Ventral view of the medial tooth from $E$. sericatus with ventro lateral cusps $(V C)$, lateral indentations $(I)$ and two lateral ridges ( $L R 1$ and $L R 2)$ which terminate as sharp anterior pointing cusps (asterisk).

Anterior (Ant) posterior (Post) orientation of the medial tooth is also indicated. b Lateral tooth from the gastric mill of E. sericatus with 8 curved cusps (numbered 1-8), ventral cusp $(V C)$ and bumpy ridges on the posterior part of the tooth (asterisk). Orientation of the tooth as in vivo is also indicated Anterior (Ant), Posterior (Post). c Lateral view of the medial tooth and right lateral tooth with lateral accessory tooth (arrow) and setal brush (asterisk). d Ventral view of the gastric mill of E. sericatus with medial $(M T)$ and lateral teeth $(L T)$. Anterior (Ant) posterior (Post) orientation of the gastric mill is also indicated. e Medial tooth from $C$. destructor with ventrally raised posterior (Post) portion with indentations on the lateral sides (I), laterally pointing cusps (asterisk), anterior ridge $(R)$ and lateral ridge $(L R)$ immediately anterior $(A n t)$ of the ventral protrusion. File like surface of the indentation on the lateral side of the ventral protrusion is also indicated with an arrow. f Lateral tooth from the gastric mill of C. destructor with 4 distinct cusps [numbered 1-4 from the anterior portion (ant) of the tooth], ventral incisor like cusp $(I C)$ and bumpy sole $(S)$ of the posterior part of the tooth. g Ventral view of the gastric mill of $C$. destructor with medial tooth $(M T)$, lateral teeth $(L T)$, lateral accessory tooth (asterisk) and setal brush (arrow)
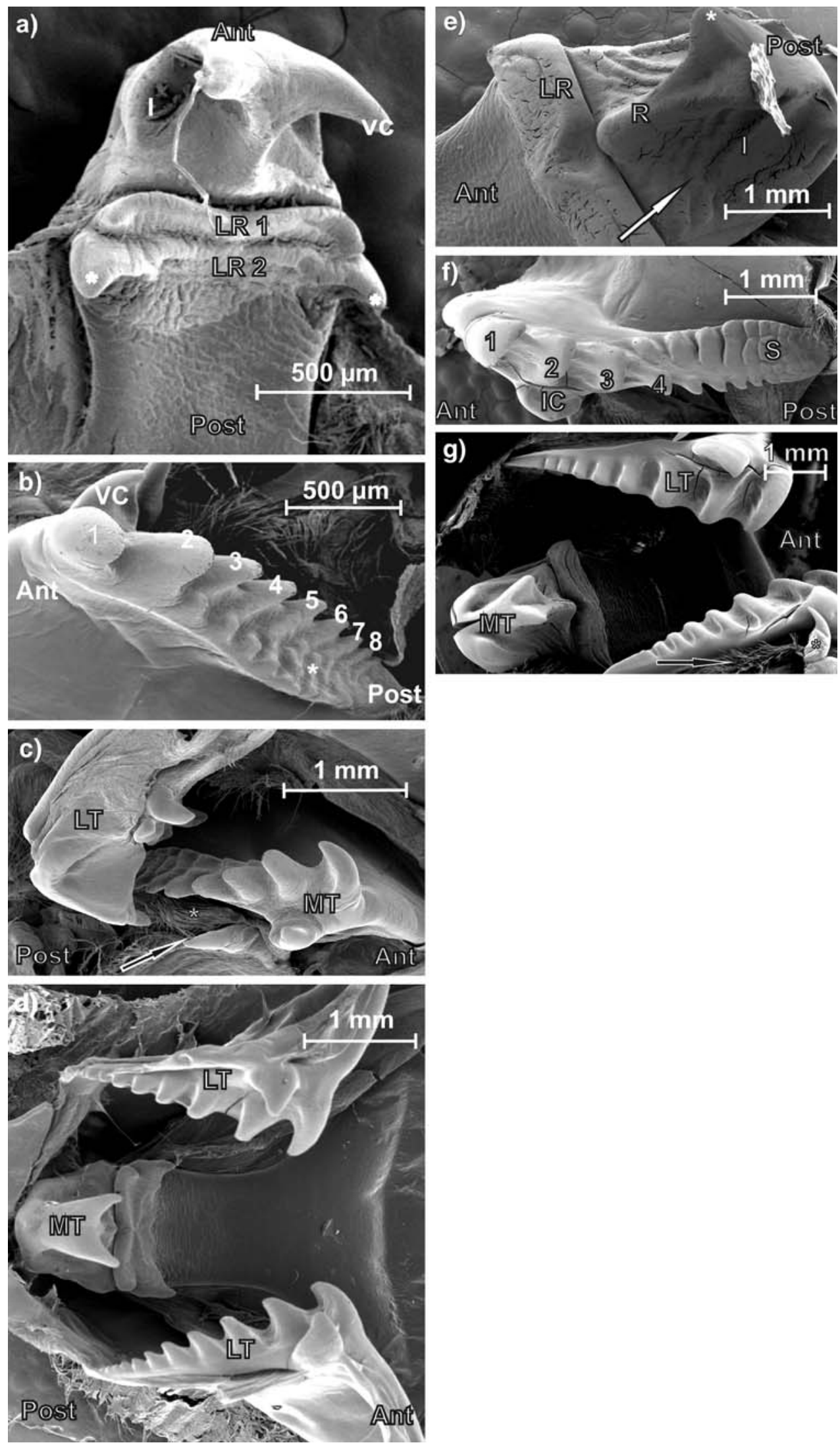
the lateral teeth of intermoult animals appeared to be slightly longer and sharper than those of premoult animals (not shown).

The lateral accessory tooth consisted of a large cone shaped cusp $(\approx 590 \mu \mathrm{m})$ which was ventral to the lateral tooth and pointed posteriorly (Fig. 1c). In between the lateral accessory tooth and the lateral teeth was a row of brush like setae (Fig. 1c).

The lateral teeth were positioned parallel to the urocardiac ossicle, which contained the medial tooth (Fig. 1d). The medial and lateral teeth were brown, indicating that the cuticle covering the teeth was possibly tanned. The serrations of the lateral teeth fitted into the triangular indentation on the medial tooth (Fig. 1c). Anterior pointing cusps on the medial tooth fitted in between the ventral cusps and cusp one on the lateral tooth.

\section{Cherax destructor}

The posterior part of the urocardiac ossicle was dentate and formed the medial tooth. The posterior part of the medial tooth was raised ventrally and ended in two lateral pointing cusps (Fig. 1e). This is in contrast to that of E. sericatus, where the medial protrusion of the medial tooth terminated as anterior pointing cusps (Fig. 1a, c). In between these cusps was a $\mathrm{V}$ shaped valley that formed into an anterior ridge (Fig. 1e). On the lateral sides of the ventral protrusion were two indentations. Their surfaces had a file like appearance. Anterior to the protrusion of the medial tooth was one rounded lateral ridge. The ridge was $\mathrm{W}$ shaped with a raised central portion. Unlike the lateral ridges of the medial tooth of E. sericutus these ridges did not terminate as sharp lateral cusps (Fig. 1a, e). The urocardiac ossicle immediately anterior to the dentate medial tooth sloped away dorsally.

Four distinct rectangular cusps were present at the anterior end of the lateral tooth (Fig. 1f). These cusps were interconnected by an anterior-posterior ridge. In premoult animals, these cusps were worn down to the level of this anterior-posterior ridge. On the ventral side of cusp numbered two and three was a cusp which superficially resembled an incisor. Posterior to these four cusps was a flat sole like structure, the surface of which was bumpy in intermoult animals. In contrast, this surface was worn flat and displayed scoring marks that ran along the anteriorposterior axis in a premoult animal. The lateral tooth thus displayed obvious wear, which must have occurred over the moult cycle. The structure of the lateral teeth of $C$. destructor was considerably different to that of E. sericatus. The lateral teeth of E. sericatus possessed sharp triangular cusps for cutting while the cusps of the lateral teeth from $C$. destructor were rectangular with a sole like posterior part (Fig. 1b, f).
The lateral accessory tooth consisted of three curved peg like cusps (Fig. 1g). These cusps were ventral to the lateral tooth and pointed posteriorly. Posterior to the lateral accessory tooth and ventral to the lateral tooth was a row of brush like setae.

The lateral teeth were parallel to the urocardiac ossicle containing the medial tooth (Fig. 1g). The sole like posterior part of the lateral teeth faced the ventral protrusion of the medial tooth. This sole like plate of the lateral teeth may have abutted against the file like surface of the most dorsal part of the posterior protrusion of the medial tooth. This may have represented the grinding part of the gastric mill.

Like E. sericatus, the serrated dorsal edge of the anterior part of the lateral tooth may have fitted into the lateral indentations on the medial tooth (Fig. 1g). The ravines between these cutting teeth were not as distinct as those of E. sericatus, given the presence of the anterior-posterior ridge. The anterior ventral incisor like cusp on the lateral teeth may have complemented the ventral lateral cusps of the protrusion of the medial tooth. The lateral teeth may have been able to rotate on the anterior-posterior axis to meet in the middle of the $\mathrm{V}$ shaped valley between the lateral cusps of the medial tooth.

\section{Lipid content and composition of lipid classes}

The midgut gland of both E. sericatus and $C$. destructor contained similar amounts of total lipid (Table 3). In either species, the lipids were dominated by triacylglycerols (81$82 \%$ of total lipids) which amounted to approximately $50 \%$ of the dry mass. Wax esters were present in the midgut gland of both species, but their concentration was higher in $E$. sericatus than in $C$. destructor (Table 3 ). Free fatty acids and sterols were not detected in the midgut gland of either species. Polar lipids comprised $10-15 \%$ of total lipids and their levels were significantly higher in the midgut gland of C. destructor than in that of E. sericatus (Table 3).

Fatty acids and fatty alcohols

Of the three saturated fatty acids (14:0, 16:0, and 18:0) identified, fatty acid 16:0 was the most predominant, comprising 16 and $18 \%$ of total lipid in E. sericatus and C. destructor respectively (Fig. 2a). The amounts of the fatty acids 14:0 and 16:0 did not differ significantly between species while the amount of 18:0 was significantly higher in the midgut gland of E. sericatus than in that of $C$. destructor.

Another major fatty acid was the monounsaturated fatty acid 18:1( $\omega-9)$. Its levels in the midgut gland of both species were similar and it made up $13 \%$ of total fatty acids in C. destructor and $16 \%$ of total fatty acids in E. sericatus (Fig. 2a). However, the levels of two other monounsatu-

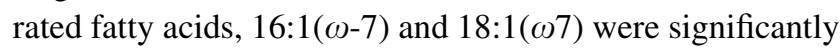
higher in the midgut gland of E. sericatus (Fig. 2a). 
Table 3 Total lipid concentration and composition of lipid classes from the midgut glands of Cherax destructor $(n=7)$ and Engaeus sericatus $(n=8)$ in terms of percentage of dry mass (\%DM) and percentage of total lipids (\%TL)

\begin{tabular}{|c|c|c|c|}
\hline & $\begin{array}{l}\text { Cherax } \\
\text { destructor }\end{array}$ & $\begin{array}{l}\text { Engaeus } \\
\text { sericatus }\end{array}$ & \\
\hline \multicolumn{4}{|c|}{ Total lipids (TL) } \\
\hline$\% \mathrm{DM}$ & $56.4 \pm 4.3^{\mathrm{a}}$ & $63.0 \pm 6.2^{\mathrm{a}}$ & \\
\hline \multicolumn{4}{|c|}{ Neutral lipids } \\
\hline \multicolumn{4}{|c|}{ Wax esters (WE) } \\
\hline$\% \mathrm{DM}$ & $1.9 \pm 0.8^{\mathrm{a}}$ & $4.9 \pm 0.9^{b}$ & \\
\hline$\% \mathrm{TL}$ & $3.3 \pm 1.5^{\mathrm{a}}$ & $8.1 \pm 1.4^{\mathrm{b}}$ & \\
\hline \multicolumn{4}{|c|}{ Triacylglycerols (TAG) } \\
\hline$\% \mathrm{DM}$ & $49.2 \pm 3.3^{\mathrm{a}}$ & $51.4 \pm 5.4^{\mathrm{a}}$ & \\
\hline$\% \mathrm{TL}$ & $81.6 \pm 2.1^{\mathrm{a}}$ & $81.0 \pm 1.6^{\mathrm{a}}$ & \\
\hline \multicolumn{4}{|c|}{ Free fatty acids (FFA) } \\
\hline$\% \mathrm{DM}$ & $0 \pm 0$ & $0 \pm 0$ & NT \\
\hline$\% \mathrm{TL}$ & $0.1 \pm 0.1$ & $0.1 \pm 0.1$ & NT \\
\hline \multicolumn{4}{|c|}{ Sterols (ST) } \\
\hline$\% \mathrm{DM}$ & $0 \pm 0$ & $0 \pm 0$ & NT \\
\hline$\% \mathrm{TL}$ & $0 \pm 0$ & $0.1 \pm 0.1$ & NT \\
\hline \multicolumn{4}{|c|}{ Membrane lipids } \\
\hline \multicolumn{4}{|c|}{ Polar lipids (PL) } \\
\hline$\% \mathrm{DM}$ & $8.8 \pm 0.4^{\mathrm{a}}$ & $6.7 \pm 0.7^{\mathrm{b}}$ & \\
\hline$\% \mathrm{TL}$ & $15.0 \pm 1.2^{\mathrm{a}}$ & $10.7 \pm 0.7^{\mathrm{b}}$ & \\
\hline
\end{tabular}

Mean values \pm SEM. Within a row, different superscript letters indicate statistically different mean values $(P<0.05, t$ test $)$

$N T$ not tested

The polyunsaturated fatty acid (PUFA) 18:2( $\omega-6)$ dominated the polyunsaturated fatty acids in $C$. destructor. In contrast, the PUFAs from the midgut gland of E. sericatus were not dominated by one particular fatty acid (Fig. 2a). The levels of the PUFAs, 18:2( $\omega-6), 18: 3(\omega-3), 20: 2(\omega-6)$

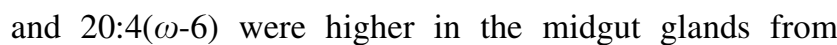
$C$. destructor than the midgut glands from E. sericatus. In contrast, the amounts of the PUFAs 20:5( $\omega-3)$ and 22:6( $\omega-3)$ were significantly higher in the midgut glands from E. sericatus (Fig. 2a). Unidentifiable fatty acids were present in the midgut glands of both species. Their amount, however, was small and reached $3.5 \%$ in E. sericatus and $5.7 \%$ in $C$. destructor (Fig. 2a). Fatty alcohols were not present in $C$. destructor, but traces of the fatty alcohols 14:0A, 16:0A and 18:0A were present in the midgut gland of 4 out of 8 specimens of E. sericatus. However, these values did not exceed $0.5 \%$ the total amount of fatty acids.

The dominating fatty acids from plant material were $16: 0,18: 2(\omega-6)$, and 18:3( $\omega-3)$ amounting to $16-26 \%$ of total fatty acids (Fig. 2b). The monounsaturated fatty acid $18: 1(\omega-9)$ accounted for $6 \%$ of total fatty acids. Each of the other fatty acids amounted to less than $2 \%$ of the total fatty acids except the fraction of unidentifiable fatty acids, which accounted for $9 \%$ of all fatty acids.

The similarity analysis of the fatty acid yields (\%) revealed three distinct clusters separating the plant material samples from the crayfish midgut glands at the $70 \%$ similarity level and distinguishing between both crayfish species at the $82 \%$ level (Fig. 3).

Enzyme activities

Total cellulase activity measures the production of glucose from the hydrolysis of cellulose. The midgut gland of both E. sericatus and C. destructor possessed low activities of total cellulase (Fig. 4). Although variable the total cellulase activity in the midgut gland of E. sericatus was 2.7 times higher than that of $C$. destructor (Fig. 2). Given cellobiohydrolase is purported to be absent in arthropods, the combined action of endo- $\beta$-1,4-glucanase and $\beta$-1,4-glucosidase may
Fig. 2 Percentage composition of selected fatty acids ( $>1 \%$ of total fatty acids) from the midgut glands of the crayfish, Cherax destructor and Engaeus sericatus (a) and from plant material (b) taken at the sampling sites. Mean values + SEM of $n=8$, each. Levels of significance between species are indicated by asterisks at $\left.P<0.05^{*}\right)$, $P<0.01 \%$ (**), and $P<0.001 \%$ $(* * *)$. The grey bars emphasize the dominating fatty acids

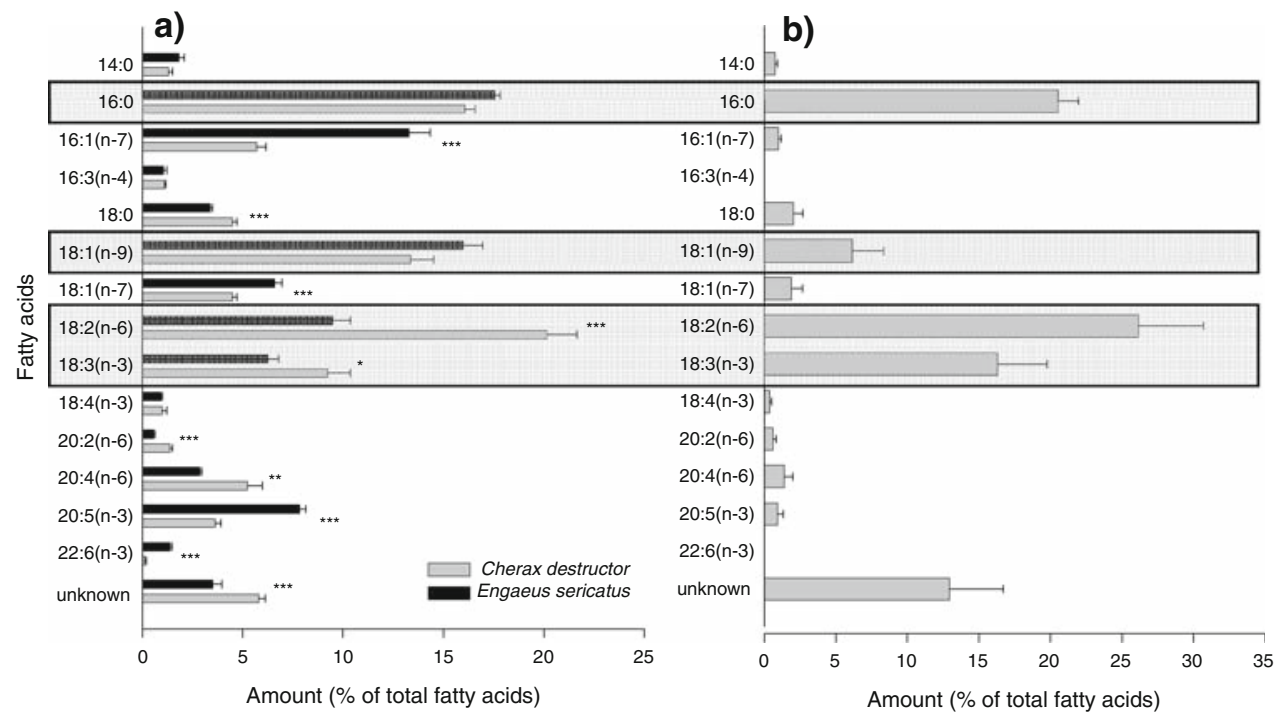




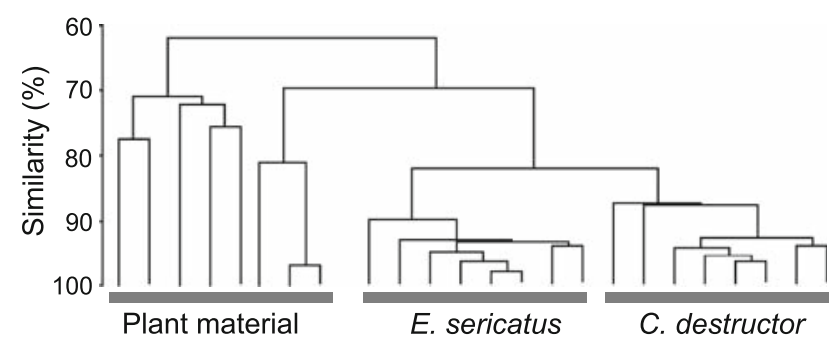

Fig. 3 Dendrogram of Bray-Curtis similarities between the fatty acid patterns of plant material, and the midgut glands of the crayfishes E. sericatus and C. destructor

account for the total cellulase activity (Scrivener and Slaytor 1994; Watanabe et al. 1997). Consistent with this, the endo- $\beta-1,4$-glucanase and $\beta$-glucosidase activities in the midgut gland of E. sericatus were, respectively, 2.3 and 3.4 times higher than that of $C$. destructor (Fig. 4). Endo- $\beta$ 1,4 -glucanase activity was the highest of all of the cellulase and hemicellulase enzymes measured.

The midgut gland of both E. sericatus and C. destructor possess similar but substantial activities of the hemicellulase enzymes, laminarinase, xylanase and lichenase (Fig. 5). The order of decreasing enzyme activity was laminarinase, lichenase and xylanase.
The midgut gland of both species contained similar activities of endochitinase (Fig. 6). However, the activity of $N$-acetyl- $\beta$-D-glucosaminidase was higher in the midgut gland of $C$. destructor than in that of E. sericatus.

The total protease activity in the midgut gland of C. destructor was higher than that of E. sericatus (Fig. 7). In contrast, the midgut gland of E. sericatus contained higher activities of chymotrypsin like protease and alanineaminopeptidase than the midgut gland of $C$. destructor. The midgut glands of both species showed similar levels of trypsin like protease.

\section{Proteinase classes}

In the midgut gland of both species, the serine proteinases dominated the proteinases given the serine proteinase inhibitor AEBSF reduced total proteolytic activity by more than $50 \%$ in C. destructor and $75 \%$ in E. sericatus (Fig. 8). Low levels of cysteine proteinase were present in the midgut glands of both species. The cysteine proteinase inhibitor E64 reduced total proteolytic activity by $20 \%$ in C. destructor and 5\% in E. sericatus. $20 \%$ and $15 \%$ of total proteolytic activity remained, respectively, in E. sericatus and $C$. destructor after inhibition of both the serine and cysteine proteinases.
Fig. 4 Activities of total cellulase ( $\mu \mathrm{mol}$ glucose $\min ^{-1} \mathrm{~g}^{-1}$ tissue) (a), endo- $\beta$ 1,4-glucanase ( $\mu \mathrm{mol}$ reducing sugars produced $\min ^{-1} \mathrm{~g}^{-1}$ tissue) (b) and $\beta$-glucosidase ( $\mu$ mol glucose $\min ^{-1} \mathrm{~g}^{-1}$ tissue) (c) in the midgut glands of Cherax destructor (C.d.) and Engaeus sericatus (E. s.). The bars represent mean values + SEM of $n=6-9$ animals. Asterisks indicate that the mean values between species were statistically different $(P<0.05)$
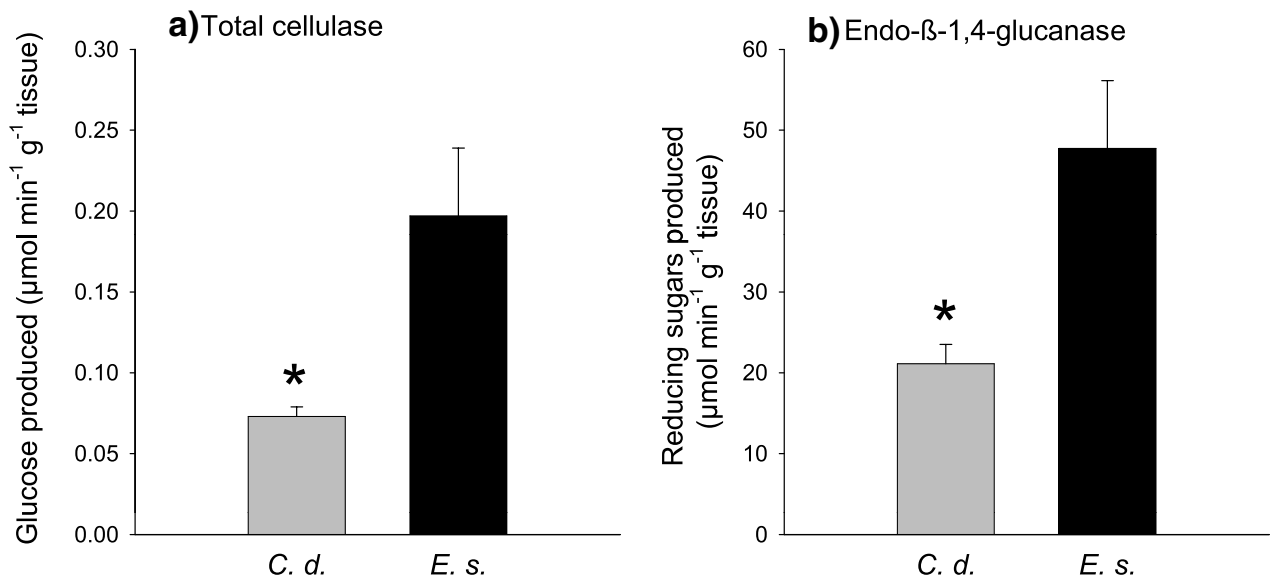

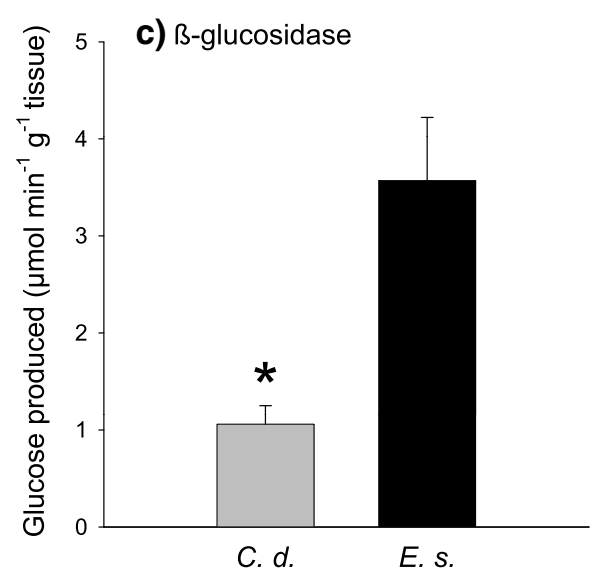


Fig. 5 Activities of hemicellulose degrading enzymes, laminarinase $(\mu \mathrm{mol}$ reducing sugars produced $\min ^{-1} \mathrm{~g}^{-1}$ tissue) (a), xylanase $(\mu \mathrm{mol}$ reducing sugars produced $\min ^{-1} \mathrm{~g}^{-1}$ tissue) (b) and lichenase ( $\mu$ mol reducing sugars produced $\mathrm{min}^{-1} \mathrm{~g}^{-1}$ tissue) (c) in the midgut glands of Cherax destructor $(C . d$.) and Engaeus sericatus (E. s.). The bars represent mean values + SEM of $n=6-9$ animals. Bars above the mean values indicate that the enzyme activities were statistically similar between species $(P \geq 0.05)$ a) Laminarinase
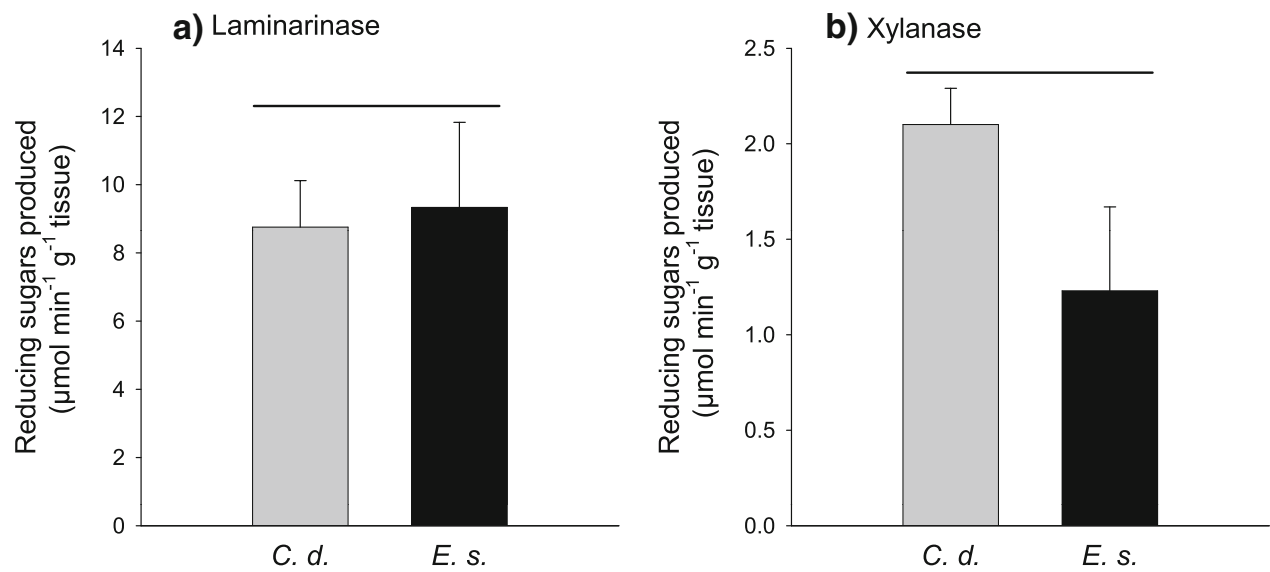

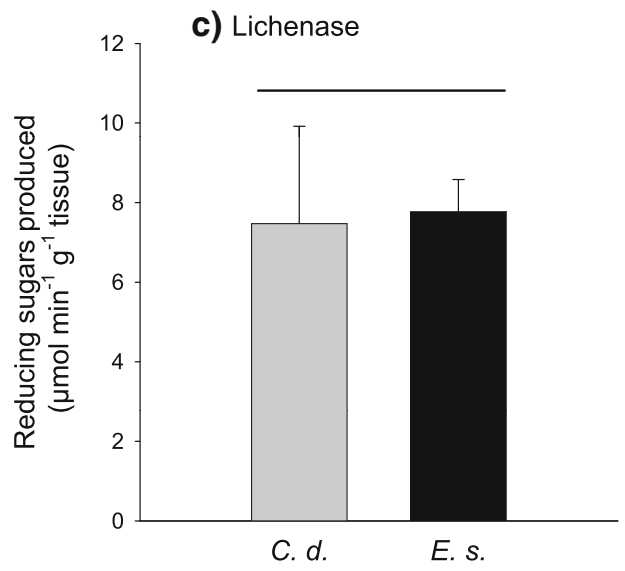

a) Endochitinase

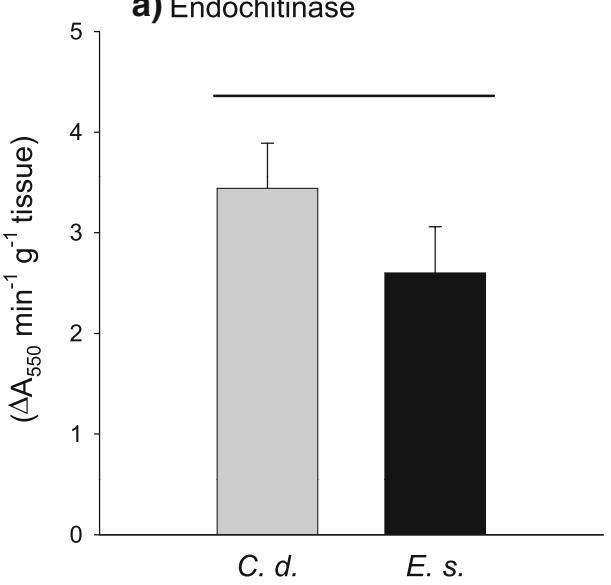

Fig. 6 Activities of chitin degrading enzymes endo-chitinase $(\Delta$ absorbance $550 \mathrm{~nm} \mathrm{~min}^{-1} \mathrm{~g}^{-1}$ tissue) (a) and $N$-acetyl- $\beta$-D-glucosaminidase ( $\Delta$ absorbance $405 \mathrm{~nm} \mathrm{~min}^{-1} \mathrm{~g}^{-1}$ tissue) (b) in the midgut glands of Cherax destructor (C. d.) and Engaeus sericatus (E. s.). The bars represent mean values + SEM of $n=6-9$ animals. The bar above

\section{Discussion}

In this study, we compared the feeding ecology and physiology of two closely related crayfish species by means of the gastric mill morphology, gut contents, storage lipids and

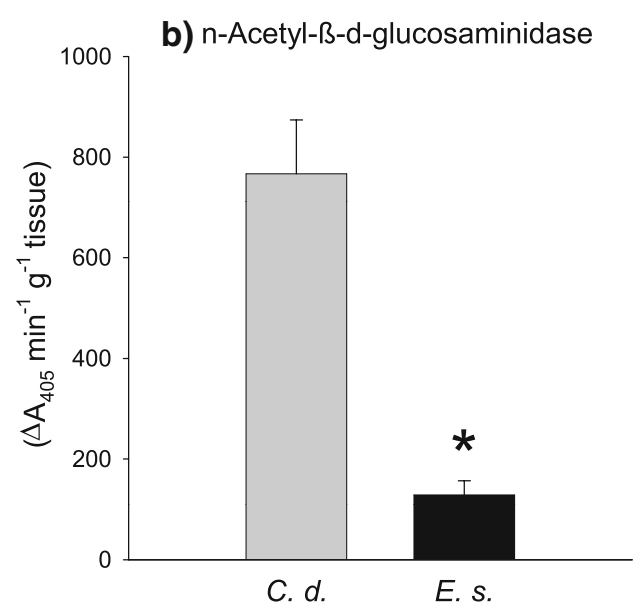

the means for endo-chitinase activity indicate that it was statistically similar between species $(P>0.05)$, while the asterisk indicates that the $N$-acetyl- $\beta$-D-glucosaminidase activity between species was statistically different $(P<0.05)$

fatty acid composition in the midgut gland, and the enzymatic ability to cleave protein, chitin and plant structural compounds such as cellulose and hemicellulose. These results revealed adaptations related to the utilisation of plant material as a consequence of the colonisation of land. 
Fig. 7 Activities of total proteinase $(\Delta$ absorbance $366 \mathrm{~nm} \mathrm{~min}^{-1} \mathrm{~g}^{-1}$ tissue) (a) and protein degrading enzymes trypsin $(\mu \mathrm{mol} p$-nitrophenol $\min ^{-1} \mathrm{~g}^{-1}$ tissue) (b), chymotrypsin ( $\mu \mathrm{mol} p$-nitrophenol $\min ^{-1} \mathrm{~g}^{-1}$ tissue) (c) and alanine-aminopeptidase $(\mu \mathrm{mol}$ $p$-nitrophenol min $^{-1} \mathrm{~g}^{-1}$ tissue) (d) in the midgut glands of Cherax destructor (C. d.) and Engaeus sericatus (E. s). The bars represent mean values + SEM of $n=6-9$ animals. The asterisks indicate that the enzyme activities differed significantly between species $(P<0.05)$, while the bars indicate that the enzyme activity was similar between species $(P>0.05)$
Fig. 8 Effects of cysteine [Trans-Epoxy-Succinyl-LLeucylamido-(4-Guanidino)Butane (E64)] and serine [4-(2-Aminoethyl)enzenesulfonyl-fluorid Hydrochloride (AEBSF)] protease inhibitors on the activities of protein degrading enzymes in the midgut glands of Cherax destructor (a) and Engaeus sericatus (b). The bars represent mean values + SEM of $n=6$ animals. Asterisks indicate that the mean values differed significantly between species $(P<0.05)$ a) Total proteinase

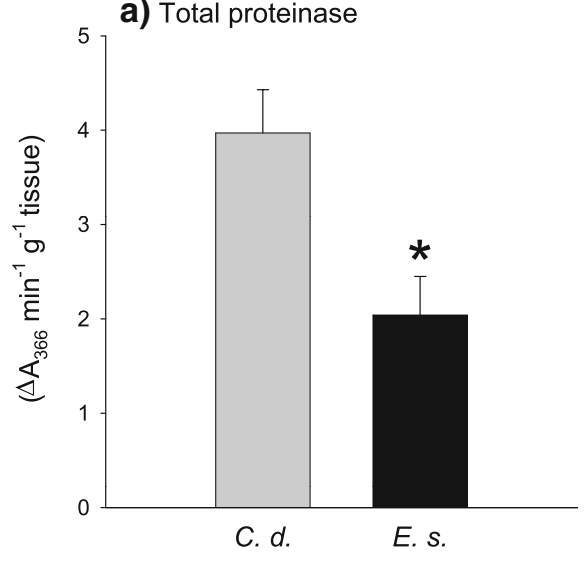

c) Chymotrypsin-like

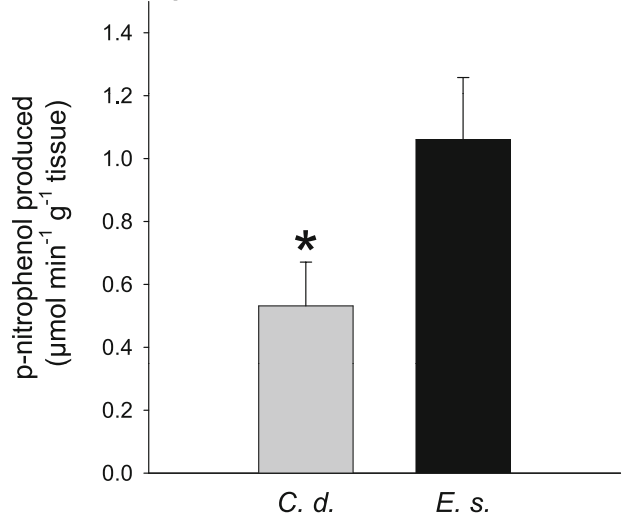

a) Cherax destructor

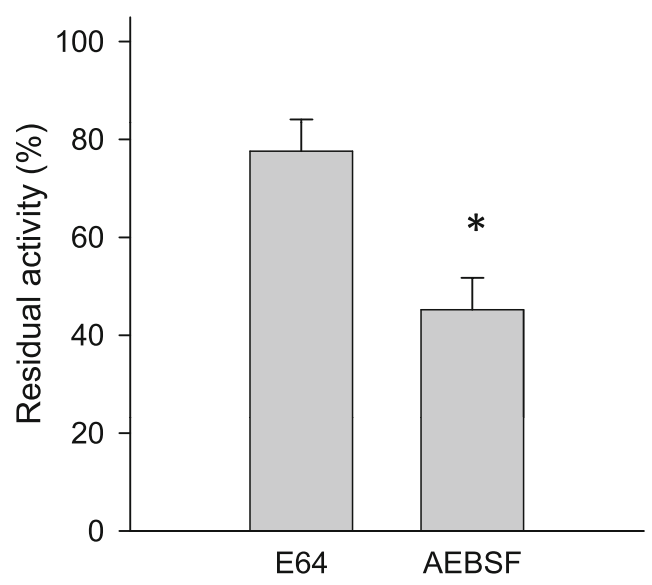

b) Trypsin-like

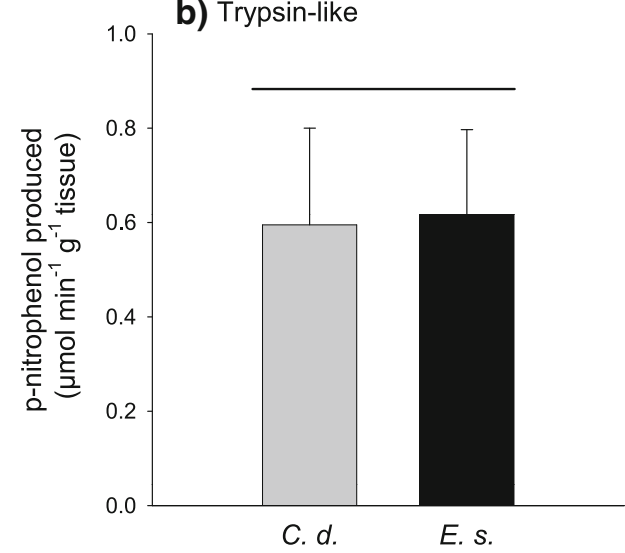

d) Alanin-aminopeptidase

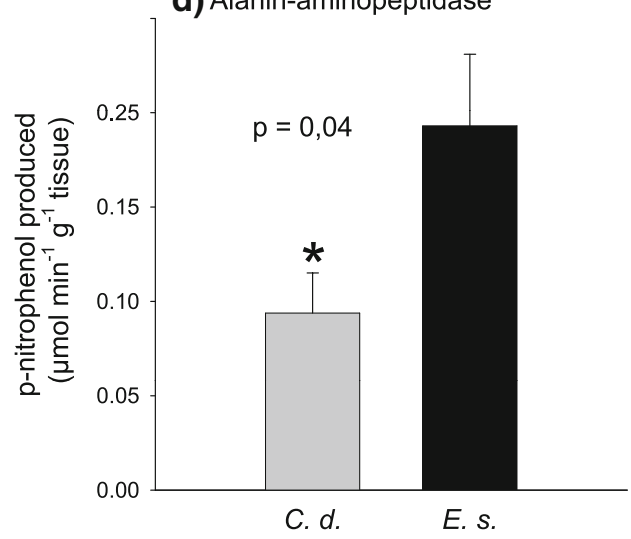

b) Engaeus sericatus

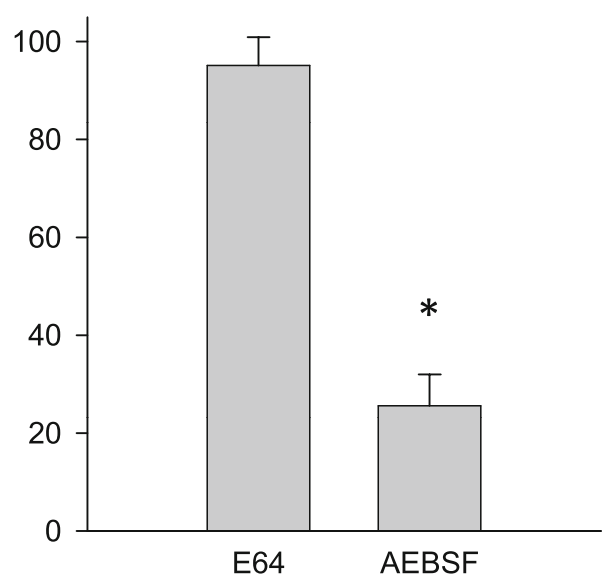

Functional morphology of the gastric mill

Both $C$. destructor and E. sericatus have well-developed gastric mills, with both species possessing ossified dentate lateral and medial teeth. The morphology of the gastric mill of E. sericatus suggests that it is primarily involved in cutting, while the morphology of the gastric mill of $C$. destructor suggests that it is primarily involved in crushing.
The coordinated movements of the medial tooth and lateral teeth of the gastric mill shreds and pulverises food material. The movements of these teeth can be divided into the cutting and grinding mode and the squeeze mode (Heinzel 1988; Heinzel et al. 1993). During the cutting and grinding mode in the gastric mill of Cherax, the posterior sole like part of the lateral teeth would meet the file like part of the medial tooth (triangular indentation on the dorso- lateral sides of the medial tooth (Fig. 1e). As the medial and lateral teeth 
move past each other food material is presumably crushed between them and rolled against the file like surface. This action would most efficiently rupture cells and release the cytoplasmic contents of soft material such as animal material and algae. At the end of the cutting and grinding mode, the four lateral cusps of the anterior part of the lateral tooth would encounter the file like surface of the medial tooth or may fit into the triangular indentation on the medial tooth (Fig. 1g). This may cut the food material and would presumably be able to cut the tough plant material. In contrast, the lateral teeth of the gastric mill from E. sericatus possess a number of serrations and hence are saw like (Fig. 1b, f). During the cutting and grinding action, these serrations of the lateral teeth would meet with the large lateral triangular indentation of the medial tooth. This cutting structure may be most efficient at cutting tough fibrous, plant material.

The lateral accessory teeth are believed to aid in the transfer of food material from the lumen of the cardiac chamber into the path of the teeth of the mill (Salindeho and Johnston 2003; Kunze and Anderson 1979). Unlike the brush-like structures found in most brachyuran species (Kunze and Anderson 1979; Martin et al. 1998), the accessory teeth of both $C$. destructor and E. sericatus are sharp, well-calcified coned shaped cusps. They are also positioned more posteriorly than in the brachyurans, indicating they may help to hold food in the mill during mastication rather than just feed material into it.

During the squeeze mode in $C$. destructor, the lateral teeth may move in and twisted on their anterior posterior axis so that the anterior ventral cusps on the lateral teeth meet with the deep V shaped valley between the ventro-lateral projecting cusps of the medial tooth (Suthers and Anderson 1981; Heinzel 1988). During a similar action in E. sericatus, the anterior pointing lateral cusps of the medial tooth may also move into the valley between the anterior serrated edge and the anterior ventro-lateral cusp of the lateral tooth. This action, depending on the force applied by the medial and lateral teeth, would either squeeze or chop pieces of food.

The general morphology of the medial and lateral teeth from the gastic mills of both $C$. destructor and E. sericatus is similar to that of other omnivorous species such as Nectocarcinus tuberculosus. That is, the lateral teeth possess cusps for cutting food material and vertical ridges for grinding (Salindeho and Johnston 2003). The medial tooth possesses surfaces for grinding and structures such as ventral pointing cusps to aid in squeezing/cutting (Salindeho and Johnston 2003).

\section{Faecal pellet contents}

The diets of both $C$. destructor and E. sericatus (Table 2) were similar to that of other burrowing parastacid crayfish such as Engaeus cisternarius, E. fossor and Parastacoides tasmanicus tasmanicus which consists of mainly plant material (roots of button grass, phloem and xylem from fallen logs, leptosporangia of the treefern, Dicksonia antartica) with minor amounts algal, fungal and animal material (Suter and Richardson 1977; Growns and Richardson 1988). Such burrowing parastacid crayfish species are mainly subterranean feeders consuming plant roots, which grow into their burrows (Gowns and Richardson 1988), and it seems likely, that plant roots serve as a valuable and easy accessible food source.

As observed in this and other studies, crayfish of the genus Cherax are also detritivores/omnivores (Faragher 1983; Beatty 2006). They consume a range of plant, algae, animal and detrital material. What they consume depends on availability and developmental stage of the animal. For example, Cherax destructor, which have been introduced into rivers in Western Australia, consume mainly adult mosquito fish (Gambusia holbrooki) in summer and mainly plant material in winter (Beatty 2006). These feeding habits reflect the availability of the dietary items. The diet of C. destructor in Lake Eucumbene, NSW, Australia consisted of mainly plant material ( $80 \%$ seeds and grasses) and minor amounts of arthropods (chironomid larvae and pupae and crayfish) (Faragher 1983).

Lipids and fatty acids

The major storage forms of lipids in crustaceans are triacylglycerides. Additionally, wax esters appear in some species. Triacylglycerides are preferentially used to cover short-term energy demands e.g. in marine copepods, whereas wax esters serve as long-term energy stores (Hagen and Auel 2001). Although low, E. sericatus showed significantly higher amounts of wax esters than $C$. destructor. Accordingly, E. sericatus may be better suited to overcome periods of starvation, which is in accordance with its life style and its preference for ephemeral habitats.

Some of the fatty acids, which were components of the triacylglycerols, were mostly likely synthesised endogenously by the crayfish and hence cannot provide reliable information on dietary preferences. Palmitic acid (16:0) and stearic acid (18:0), both of which were present in large amounts in the midgut gland of both species, are typical products of fatty acid biosynthesis in both plants and animals. Desaturation and elongation of palmitic acid (16:0) to produce palmitoleate (16:1) and oleate (18:1) are known to endogenously occur in copepods and may also take place in the midgut gland of the crayfish. In contrast the poly unsaturated fatty acids, linoleate $(18: 2(\omega-6))$ and linolenate $(18: 3(\omega-3))$ are synthesised by plants and not animals and are indicative of the consumption of terrestrial plant material in coastal marine ecosystems (Budge et al. 2001). In the 
midgut glands of both species, these fatty acids separately accounted for more than $15 \%$ and together accounted for more than $40 \%$ of total fatty acids. This suggests that both $C$. destructor and E. sericatus consumed substantial amounts of terrestrial plants. However, the amounts of each fatty acid were significantly higher in $C$. destructor than in $E$. sericatus indicating that $C$. destructor may have ingested and assimilated more plant material than E. sericatus.

Similarity analysis revealed that the fatty acid composition not only distinctly differed between plants and crayfishes but also between both crayfish species. Although the crayfishes obviously accumulated typical plant fatty acids [18:2( $\omega-6)$ and 18:3( $\omega-3)]$, many other fatty acids did not match with the pattern of the analysed plants due to endogenous conversion of fatty acids or due to the accumulation of fatty acids from other food sources than those analysed. Particularly, smaller invertebrates including insects and annelids form staple dietary items as shown by gut content analysis. The different fatty acid patterns between C. destructor and E. sericatus are certainly due to differences and quantities of diets but may also be related to differences of metabolic pathways of either species.

\section{Digestive enzymes}

Both species are able to hydrolyse cellulose associated with the cell walls of plants. However, E. sericatus seems to be more efficient at cellulose hydrolysis than $C$. destructor because the midgut gland of the former species shows higher activities of total cellulase and the enzymes contributing to this, endo- $\beta$-1,4-glucanase and $\beta$-glucosidase. E. sericatus is thus better able to hydrolyse, digest and utilise cellulose than $C$. destructor. Since both species are closely related, the higher total cellulase, endo- $\beta-1,4$-glucanase and $\beta-1,4$-glucosidase activity may indicate that E. sericatus has adapted to a diet containing more terrestrial plant material.

Hemicellulases, laminarinase, lichenase and xylanase were present at similar levels in the midgut glands of both E. sericatus and C. destructor. Xylanase activity is indicative of the ability to hydrolyse xylan, a common structural polysaccaride present in the cell walls of grasses and other angiosperms (Bacic et al. 1988). Lichenase activity indicates that both species are able to hydrolyse lichenan or mixed linkage $\beta$-glucans. Lichenan or mixed linkage $\beta$-glucan is composed of glucose units joined by mainly $\beta-1,4$ glycosidic bonds with some $\beta-1,3$ linkages and is a major component of the cell walls of cereals and grasses (McCleary 1988; Terra and Ferreira 1994). Xylanase and lichenase activities, along with the total cellulase activity indicate that both species are capable of digesting the major components of the cell walls of grasses, which may be commonly found in their respective habitats. Laminarianse activity indicates that both $E$. sericatus and $C$. desctructor are able to hydrolyse laminarin. Laminarin is a principally $\beta-1,3$ glycosidic bond glucose polymer (Terra and Ferreira 1994). It is a common storage polysaccharide of algae but also present in phloem and plant wound tissue (Vonk and Western 1984; Terra and Ferreira 1994). Thus, both species may be able to digest algae. E. sericatus feeds on roots growing into their feeding chambers. These roots may contain substantial amounts of wound tissue and hence laminarin.

The ability to digest the plant compounds cellulose and hemicellulose is widespread amongst the Crustacea (reviewed by Linton and Greenaway 2007). The presence of xylanase and lichenase, however, has recieved scant attention. Like laminarinase, these enzymes may be widely distributed throughout the Crustacea. However they may only be present in species that encounter these substrates in their diet (Crawford et al. 2005).

Despite contradicting reports published recently (Pavasovic et al. 2006), the cellulases and hemicellulases are most likely responsible for the digestion of dietary fibre. Assimilation co-efficients for crude fibre by Cherax destructor fed an artificial diet were high (Jones and De Silva 1997) indicating that the activity of cellulase enzymes may account for such cellulose digestion. Similarly higher cellulose assimilation co-efficients for the gecarcinid crabs, Gecarcoidea natalis and Discoplax hirtipes fed brown leaves is correlated with higher total cellulase activities in these species (Greenaway and Linton 1995; Linton and Greenaway 2004). In addition, high hemicellulose assimilation co-efficients for $G$. natalis and D. hirtipes fed a brown leaf litter diet correlated well with substantial activities of the hemicellulase enzymes, laminarinase, lichenases and xylanase (Linton and Greenaway 2004).

$C$. destructor and E. sericatus both possess proteinases for hydrolysing protein associated with plant and animal material. Higher total protease activity in $C$. destructor may indicate that this species has a higher intake of animal material than E. sericatus. Like decapods generally, the proteases present in the midgut glands of both $C$. destructor and $E$. sericatus were mainly serine proteinases (trypsinand chymotrypsin-like enzymes) with a small amounts of cysteine proteinases (Ceccaldi 1997; Johnston and Yellowlees 1998; Lehnert and Johnson 2002; Navarrete del Toro et al. 2006; Gudmundsdottir 2002). The proteolytic activity remaining after the inhibition of both serine and cysteine proteinases (20\% in E. sericatus and $15 \%$ in C. destructor) may represent activity of aspartyl proteases and metalloproteases such as carboxypeptidase $\mathrm{A}$ and carboxypeptidase B.

Both E. sericatus and C. destructor possessed substantial activities of endochitinase and $N$-acetyl- $\beta$-D-glucosaminidase. Both enzymes work in concert to hydrolyse 
chitin to its monomer of $N$-acetyl-glucosamine. Endochitinase hydrolyses the internal glycosidic bonds of chitin to produce dimers and trimers of $N$-acetyl-D-glucosamine (Kono et al. 1990; Genta et al. 2006). $N$-acetyl- $\beta$-D-glucosaminidase then hydrolyses the oligomers into monomers (Peters et al. 1999; Zou and Fingerman 1999; Xie et al. 2004). Chitinase enzymes are ubiquitous throughout the Crustacea acting as both a moulting and digestive enzyme (Zou and Fingerman 1999; Peters et al. 1999). C. destructor may be more efficient at digesting arthropod chitin given its midgut gland possessed a higher activity of $N$-acetyl- $\beta$-D-glucosaminidase than the midgut gland of E. sericatus. This, plus the higher total protease activity within the midgut gland suggests that C. destructor is better suited to digest animal tissue, e.g. from arthropods than E. sericatus.

The presence of proteinases, endo- $\beta-1,4$-glucanase, $\beta-1,4$-glucanase, xylanase, lichenase and, laminarinase has been documented previously in Cherax species (Crawford et al. 2005; Figueiredo et al. 2001). Crayfish of the genus Cherax are omnivorous consuming mainly plant material and clearly their digestive enzyme complement correlates well with the substrates that they would encounter in their natural diet.

\section{Conclusion}

Both $C$. destructor and E. sericatus are omnivorous, consuming a range of plant, animal and algal material. The complement of digestive enzymes (proteinases, laminarinase, lichenase, xylanase, total cellulase, endo- $\beta$-1,4-glucosidase, $\beta-1,4$-glucosidase) within the midgut gland suggests that both species are capable of efficiently hydrolysing the wide variety of substrates associated with such a diet. E. sericatus seems to be better adapted to cope with terrestrial plant material than $C$. destructor given its midgut gland possess higher activities of total cellulase, endo- $\beta-1$, 4-glucanase and $\beta-1,4$-glucosidase and the morphology of the gastric mill suggests that it is better able to cut fibrous plant material. In contrast, the morphology of the gastric mill and the higher total cellulase and $N$-acetyl- $\beta$-D-glucoasminidase activities possessed by $C$. destructor suggests that this species is better able to digest animal material in the form of arthropods. Given that E. sericatus and C. destructor are closely related (Crandall et al. 1999), the differences in enzyme activity and morphology of the gastric mill observed between the two species may represent $E$. sericatus being better adapted to digest terrestrial plant material. The contents of the faeces suggest that while both species consumes large amounts of plant material, C. destructor consumes significantly more aquatic macroalgae.
Acknowledgments The International Office of the German Ministry of Education and Research supported this work by a travel grant to R. Saborowski (AUS 02/06A). The Hermon Slade Foundation provided a research grant to $\mathrm{S}$. Linton.

\section{References}

Bacic A, Harris PJ, Stone BA (1988) Structure and function of plant cell wall. In: Stumpf PK, Conn EE (eds) The Biochemistry of Plants Vol 14. Academic Press, New York, pp 297-371

Beatty SJ (2006) The diet and trophic positions of translocated, sympatric populations of Cherax destructor and Cherax cainii in the Hutt River, Western Australia: evidence of resource overlap. Mar Freshw Res 57:825-835

Bradford MM (1976) A rapid and sensitive method for the quantitation of microgram quantities of protein utilizing the principle of protein-dye binding. Anal Biochem 72:248-254

Budge SM, Parrish CC, Mckenzie CH (2001) Fatty acid composition of phytoplankton, settling particulate matter and sediments at a sheltered bivalve aquaculture site. Mar Chem 76:285-303

Ceccaldi HJ (1997) Anatomy and physiology of the digestive system. In: D'Abramo LR, Conklin DE, Akiyama DM (eds) Advances in world aquaculture, vol. 6, Crustacean nutrition. The world aquaculture society, Louisiana state university, Baton Rouge, pp 261-291

Crandall KA, Fetzner JW, Lawler SH, Kinnersley M, Austin CM (1999) Phylogenetic relationships among the Australian and New Zealand genera of freshwater crayfishes (Decapoda: Parastacidae). Aust J Zool 47:199-214

Crawford AC, Richardson NR, Mather PB (2005) A comparative study of cellulase and xylanase activity in freshwater crayfish and marine prawns. Aquac Res 36:586-592

Dalsgaard J, St John M, Kattner G, Müller-Navarra D, Hagen W (2003) Fatty acid trophic markers in the pelagic marine environment. Adv Mar Biol 46:225-340

Erlanger BF, Kokowsky N, Cohen W (1961) The preparation and properties of two new chromogenic substrates for trypsin. Arch Biochem Biophys 95:271-278

Faragher RA (1983) Role of the crayfish Cherax destructor Clark as food for trout in Lake Eucumbene, New South Wales. Aust J Mar Freshw Res 34:407-417

Figueiredo MSRB, Kricker JA, Anderson AJ (2001) Digestive enzyme activities in the alimentary tract of the redclaw crayfish, Cherax quadricarinatus (Decapoda: Parastacidae). J Crust Biol 21:334 344

Fraser AJ, Tocher DR, Sargent JR (1985) Thin-layer chromatographyflame ionization detection and the quantitation of marine neutral lipids and phospholipids. J Exp Mar Biol Ecol 88:91-100

Genta F, Blanes L, Cristofoletti PT, do Lago CL, Terra WR, Ferreira C (2006) Purification, characterisation and molecular cloning of the major chitinase from Tenebrio molitor larval midgut. Insect Biochem Mol Biol 36:789-800

Giddins RL, Lucas JS, Neilson MJ, Richards GN (1986) Feeding ecology of the mangrove crab Neosarmatium smithi (Crustacea: Decapoda: Sesarmidae). Mar Ecol Prog Ser 33:147-155

Goddard JS (1988) Food and Feeding. In: Holdich DM, Lowery RS (eds) Freshwater crayfish: biology management and exploitation. Croom Helm, London, pp 145-166

Greenaway P, Linton SM (1995) Dietary assimilation and food retention time in the herbivorous terrestrial crab Gecarcoidea natalis. Physiol Zool 68:1006-1028

Growns IO, Richardson AMM (1988) Diet and burrowing habits of the freshwater crayfish, Parastacoides tasmanicus tasmanicus Clark (Decapoda, Parastacidae). Aust J Mar Freshw Res 39:525-534 
Gudmundsdottir A (2002) Cold-adapted and mesophilic brachyurins. Biol Chem 383:1125-1131

Hagen W (2000) Lipids. In: Harris RP, Wiebe PH, Lenz J, Skjoldal HR, Huntley M (eds) ICES zooplankton methodology manual. Academic Press, San Diego, pp 113-119

Hagen W, Auel H (2001) Seasonal adaptations and the role of lipids in oceanic zooplankton. Zoology 104:313-326

Heeren T, Mitchell BD (1997) Morphology of the mouthparts, gastric mill and digestive tract of the gian crab, Pseudocarcinus gigas (Milne Edwards) (Decapoda: Oziidae). Mar Freshw Res 48:7-18

Heinzel H-G (1988) Gastric mill activity in the Lobster I. Spontaneous modes of chewing. J Neurophysiol 59:528-550

Heinzel H-G, Weinmann JM, Marder E (1993) The Behavioural repertoire of the gastric mill in the crab, Cancer pagurus: an in situ endoscopic and electrophysiological examination. J Neurosci 13:1793-1803

Horwitz P (1990) A taxonomic revision of species in the freshwater crayfish genus Engaeus Erichson (Decapoda: Parastacidae). InvertebTaxon 4:427-614

Johnston D, Freeman J (2005) Dietary preference and digestive enzymes activities as indicators of trophic resourece utilization by six species of crab. Biol Bull 208:36-46

Johnston DJ, Yellowlees D (1998) Relationship between dietary preferences and digestive enzyme complement of the slipper lobster Thenus orientalis (Decapoda: Scyllaridae). J Crust Biol 18:656665

Jones PL, De Silva SS (1997) Apparent nutrient digestibility of formulated diets by the Australian freshwater crayfish Cherax destructor Clark (Decapoda, Parastacidae). Aquac Res 28:881-891

Jones D, Morgan G (1994) A field guide to Crustaceans of Australian Waters. Reed, Sydney

Kattner G, Fricke HSG (1986) Simple gas-liquid chromatography method for the simultaneous determination of fatty acids and alcohols in wax esters of marine organisms. J Chromatogr 361:263-268

Kono M, Matusi T, Shimizu C, Koga D (1990) Purifications and some properties of chitinase from the liver of a prawn, Penaeus japonicus. Agr Biol Chem 54:2145-2147

Kunze J, Anderson DT (1979) Functional morphology of the mouthparts and gastric mill in the hermit crabs Clibanarius taeniatus (Milne Edwards), Clibanarius virescens (Krauss), Paguristes squamosus (McCulloch) and Dardanus setifer (Milne-Edwards) (Anomura: Paguridae). Aust J Mar Freshw Res 30:683-722

Lehnert SA, Johnson SE (2002) Expression of hemocyanin and digestive enzyme messenger RNAs in the hepatopancreas of the Black Tiger Shrimp, Penaues monodon. Comp Biochem Physiol B 133:163-171

Linton SM, Greenaway P (2004) Presence and properties of cellulase and hemicellulase enzymes of the gecarcinid land crabs Gecarcoidea natalis and Discoplax hirtipes. J Exp Biol 207:4095-4104

Linton SM, Greenaway P (2007) A review of feeding and nutrition of herbivorous land crabs: adaptations to low quality plant diets. J Comp Physiol B 177:269-286

Martin JW, Jourharzadeh P, Fitterer PH (1998) Description and comparison of major foregut ossicles in hydrothermal vent crabs. Mar Biol 131:259-267

McCleary BV (1988) Licheninase from Bacillus subtilis. In: Wood WA, Kellogg ST (eds) Methods in Enzymology, vol 160. Biomass Part A. Cellulose and Hemicellulose. Academic Press, New York, pp 572-575
Merrick JR (1993) Freshwater crayfishes of New South Wales. Linnean society of New South Wales, Sydney

Navarrete del Toro MDLA, Garcia-Carreno FL, Lopez MD, CelisGuerrero L, Saborowski R (2006) Aspartic proteinases in the digestive tract of marine decapod crustaceans. J Exp Zool 305A:645-654

Nelson DL, Cox MM (2005) Lehninger Principles of Biochemistry. Freeman and Company, New York, p 1119

Pavasovic A, Richardson NA, Mather PB, Anderson AJ (2006) Influence of insoluble dietary cellulose on digestive enzyme activity, feed digestibility and survival in the red claw crayfish, Cherax quadricarinatus (von Martens). Aquac Res 37:25-32

Peters G, Saborowski R, Buchholz F, Mentlein R (1999) Two distinct forms of the chitin-degrading enzyme $N$-acetyl- $\beta$-D-glucosaminidase in the Antarctic krill: specialists in digestion and moult. Mar Biol 134:697-703

Saborowski R, Buchholz F, Vetter R-A H, Wirth S, Wolf G (1993) A soluble dye-labelled chitin derivative adapted for the assay of krill chitinase. Comp Biochem Physiol B 105:673-678

Saborowski R, Sahling G, Navarette del Toro MA, Waltera I, GarcíaCarreñob FL (2004) Stability and effects of organic solvents on endopeptidases from the gastric fluid of the marine crab Cancer pagurus. J Mol Catal B: Enzymatic 30:109-118

Salindeho IR, Johnston DJ (2003) Functional morphology of the mouthparts and proventriculus of the rock crab Nectocarcinus tuberculosus (Decapoda: Purtunidae). J Mar Biol Assoc UK 83:821-834

Scrivener AM, Slaytor M (1994) Properties of the endogenous cellulase from Panesthia cribrata Saussure and purification of major endo- $\beta$-1, 4-glucanase components. Insect Biochem Mol Biol 24:223-231

Skilleter GA, Anderson DT (1986) Functional morphology of the chelipeds, mouthparts and gastric mill of Ozius truncatus (Milne Edwards) (Xanthidae) and Leptograpsus variegatus (Fabricius) (Grapsidae) (Brachyura). Aust J Mar Freshw Res 37:67-79

Suter PJ, Richardson AMM (1977) The biology of two species of Engaeus (Decapoda: Parastacidae) in Tasmania III.Habitat, food, associated fauna and distribution. Aust J Mar Freshw Res 28:95-103

Suthers IM, Anderson AJ (1981) Functional morphology of mouthparts and gastric mill of Ibacus peronii (Leach) (Palinura: Scyllaridae). Aust J Mar Freshw Res 32:931-944

Terra WR, Ferreira C (1994) Insect digestive enzymes: properties, compartmentalization and function. Comp Biochem Physiol 109B:1-62

Teschke M, Saborowski R (2005) Cysteine proteinases substitute for serine proteinases in the midgut gland of Crangon crangon and Crangon allmani (Decapoda, caridea). J Exp Mar Biol Ecol 316:213-229

Vonk HJ, Western JRH (1984) Comparative biochemistry and physiology of enzymatic digestion. Academic Press, New York

Watanabe H, Nakamura M, Tokuda G, Yamaoka I, Scrivener AM, Noda H (1997) Site of secretion and properties of endogenous endo- $\beta$-1, 4-glucanase components from Reticulitermes speratus (Kolbe), a Japanese subterranean termite. Insect Biochem Mol Biol 27:305-313

Xie X-L, Chen Q-X, Lin J-C (2004) Purification and some properties of $\beta$ - $N$-acetyl-D-glucosaminidase from prawn (Penaeus vannamei). Mar Biol 146:143-148

Zou E, Fingerman M (1999) Chitobiase activity in the epidermis and hepatopancreas of the fiddler crab Uca pugilator during the molting cycle. Mar Biol 133:97-101 